\title{
The development of PARP inhibitors in ovarian cancer: from bench to bedside
}

\author{
Yvette Drew ${ }^{\star}, 1,2$ \\ ${ }^{1}$ Northern Institute for Cancer Research, Newcastle University, Newcastle upon Tyne, UK and ${ }^{2}$ Northern Centre for Cancer Care, \\ Freeman Hospital, Newcastle upon Tyne, UK
}

The nuclear enzyme poly (ADP-ribose) polymerase (PARP) represents an important novel target in the treatment of ovarian cancer. This article charts over 50 years of research from the discovery of the first PARP enzyme in 1963, to the approval and licensing in 2015 of the first PARP inhibitor, olaparib (Lynparza), in the treatment of BRCA-mutated ovarian cancer.

Ovarian cancer is the fifth most common cancer in women in developed countries, accounting for 140000 deaths per year worldwide (World Health Organization, 2008; Siegel et al, 2012). The majority of women present with advanced-stage (3 or 4) disease, where 5-year survival rates are poor at around 27\% (Siegel et al, 2012). Despite initial high responses to platinum-based chemotherapy and cytoreductive surgery, more than $70 \%$ of these patients will relapse with limited subsequent treatment options (Hanker et al, 2012). There is a pressing need for improved treatments that can extend survival, delay disease progression and maintain quality of life for patients with ovarian cancer.

A better understanding of cancer is leading to the identification of distinct cancer molecular sub-types, new anticancer targets, and more individualised patient treatment approaches. The development of poly(ADP-ribose) polymerase (PARP) inhibitors for the treatment of BRCA-mutated (BRCAm) ovarian cancer is an example of this approach in action. This review summarises the research behind this development; charting the discovery of the first PARP enzyme (Chambon et al, 1963) and the development of PARP inhibitors as a class; highlighting why cancers defective in DNA repair could be selectively sensitive to these agents, and why the approval of the PARP inhibitor olaparib (Lynparza) has changed the management of BRCAm ovarian cancer.

\section{DNA DAMAGE RESPONSE, REPAIR PATHWAYS AND BRCA}

The accurate and efficient repair of DNA damage is essential for cells to function and maintain genomic stability (Hoeijmakers, 2001). In humans, acquired or inherited defects in DNA damage response and repair pathways can result in an increased lifetime risk of cancer (Hoeijmakers, 2009). DNA double-strand breaks (DSBs) are regarded as the most lethal of the DNA insults and, if left unrepaired, result in genomic instability, carcinogenesis and ultimately cell death (Hoeijmakers, 2001). DNA DSBs can arise as a result of direct damage to both strands of DNA from exogenous agents, such as ionising radiation or chemotherapy (Helleday et al, 2008), or as part of normal cell physiology, for example, to permit genetic recombination during meiosis (Neale and Keeney, 2006) and the rearrangements needed for the development of immunoglobulin genes during $\mathrm{V}(\mathrm{D}) \mathrm{J}$ (variable, diversity and joining) recombination (Leavy, 2010).

The two primary DSB repair pathways in humans are nonhomologous end joining (NHEJ) and homologous recombination repair (HRR). These two pathways operate independently but do share some common proteins (Figure 1). The pathway that is used to repair the DNA damage depends principally on the origin of the DSB and the stage in the cell cycle in which the DSB occurs (Takata et al, 1998). The preferred pathway is HRR, as it is an error-free pathway; however, it is dependent on the availability of sister chromatids and can only take place in late $S$ and the $G_{2}$ phases of the cell cycle (O'Driscoll and Jeggo, 2006). A significant number of DSBs can also arise during DNA replication when a replication fork encounters an unrepaired, single-strand break (SSB); the HRR pathway and the nuclear enzyme PARP-1 have a vital role in repairing these DSBs (Bryant et al, 2009; Helleday et al, 2007). Homologous recombination repair involves a variety of proteins, including BRCA1 and BRCA2. BRCA1 has a role in signalling of the DNA DSB damage response and subsequent repair via $\mathrm{HRR}$, but also in transcriptional regulation and cell-cycle checkpoint control; whereas BRCA2 has a more direct repair role in HRR through its regulation of Rad51 (Gudmundsdottir and Ashworth, 2006). It is proposed that the BRCA2-Rad51 complex

*Correspondence: Dr Y Drew; E-mail: yvette.drew@newcastle.ac.uk 
A

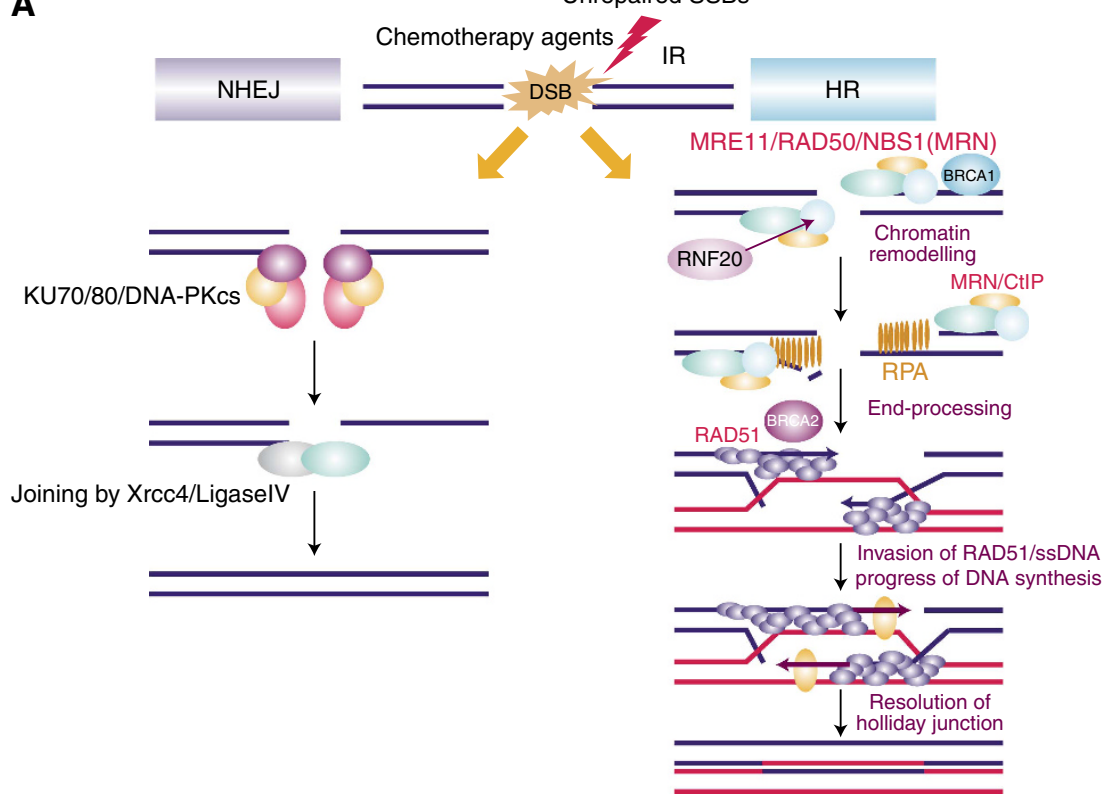

B

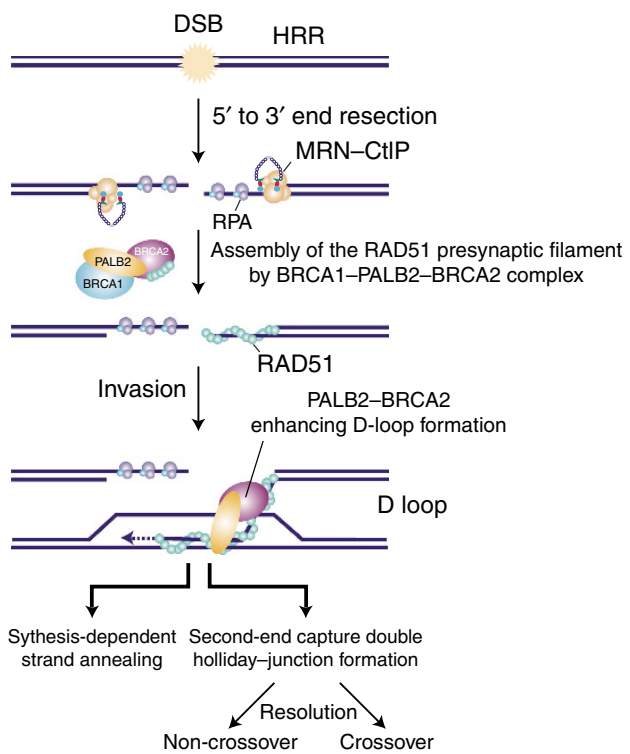

Figure 1. Mechanisms of DNA double-strand break (DSB) repair. Double-stranded breaks in DNA are typically repaired through one of two pathways: (A) non-homologous end joining (NHEJ); (A, B) homologous recombination (HR). Proteins involved in NHEJ include KU70/80, DNAPKCs, XRCC4 and DNA ligase IV. Proteins involved in HR include MRE11, RAD50 and NBS1 (which form the MRN complex); CtIP; RNF20; RPA; RAD51; PALB2; BRCA1 and BRCA2. Abbreviations: HRR, homologous recombination repair; IR, ionising radiation; SSB, single-strand break; ssDNA, single-stranded DNA. Note: (A) Reproduced with permission from Pioneer Bioscience Publishing Company (C) Saito et al, 2013). (B) Reprinted with permission from Nature America, Inc. (C) Buisson et al, 2010).

binds to the exposed DNA, and this binding then enables the loading of Rad51 onto the break and the formation of the presynaptic filament (Yang et al, 2002). Given the functions of BRCA1 and 2, it would be logical to hypothesise that deficiencies within either gene will result in defective HRR and subsequent loss of efficient and effective DNA DSB repair.

\section{BRCA MUTATIONS AND OVARIAN CANCER}

The BRCA1 gene was identified in 1990 by Mary King's group working at Berkeley, CA, USA. The name BRCA was originally chosen to stand for Berkeley California, but was later changed to represent breast cancer susceptibility (Hall et al, 1990). The gene was subsequently cloned in 1994 by Myriad Genetics (Miki et al, 1994). Around the same time, the BRCA2 gene was discovered by Stratton and Wooster working at the Institute of Cancer Research, London, UK (Wooster et al, 1994). The identification of these genes represented a significant breakthrough in the management of breast and ovarian cancer families, enabling the introduction of risk assessment, genetic counselling and BRCA mutational analysis. Subsequently, over 2000 distinct mutations and sequence variations in the BRCA genes have been identified (Audeh, 2014), with $B R C A 1$ mutations more common, occurring approximately twice as frequently as BRCA2 (Chen and Parmigiani, 2007).

Women who inherit a deleterious $B R C A 1$ or $B R C A 2$ mutation have up to a $40 \%$ and $20 \%$ lifetime risk, respectively, of developing ovarian cancer, and higher risks of developing breast cancer (Chen and Parmigiani, 2007). The prevalence of germline (g) BRCA mutations in ovarian cancer has historically been estimated to be around 10-15\% (Risch et al, 2001). However, recent reports suggest that this may be a gross underestimate, especially in women with high-grade serous ovarian cancer (HGSOC) (Risch et al, 2006; Cancer Genome Atlas Research Network, 2011; Alsop et al, 2012). In addition, in one series where
$17 \%$ of patients with HGSOC were found to carry a BRCA mutation, almost half (44\%) of these women had no family history of cancer (Alsop et al, 2012). Such data support the use of BRCA mutation testing in all patients with HGSOC, regardless of family history. This expansion in BRCA testing will require changes to the traditional genetic service pathways in which patients are screened and referred based on family history, moving to a more streamlined oncology-based genetic testing service.

Over the past two decades the main focus in the treatment of women identified as BRCA mutation carriers has been ovarian and breast cancer prevention through prophylactic surgery, and early cancer detection through screening (Domchek et al, 2006). However, surveillance and surgery will not prevent all carriers developing cancer and many already have cancer at the time their mutation status is diagnosed. The current management of $B R C A m$-associated ovarian cancer is not different to the treatment of the non-BRCA stage-matched cases. However, recent data suggest that these $B R C A \mathrm{~m}$ cancers should be treated as a distinct disease entity and that $B R C A$ mutation status has a major influence on ovarian cancer patient outcomes. In vitro studies have demonstrated that BRCA1- and 2-deficient cells are more sensitive than their wild-type controls to platinum analogues and less sensitive to anti-microtubule agents, such as the taxanes (Bhattacharyya et al, 2000; Tassone et al, 2003; Tan et al, 2008). Data from 26 observational clinical studies of 3879 women with ovarian cancer reported that those with BRCAm cancers have a better outcome following cytoreductive surgery and platinumbased chemotherapy than their non-BRCAm counterparts, with prolonged progression-free and greater 5 -year overall survival (Bolton et al, 2012). A recent meta-analysis of 14 ovarian cancer studies has confirmed this, showing that BRCA status in ovarian cancer is an independent predictor of outcome (Zhong et al, 2015). In the relapsed setting, BRCAm carriers have also been shown to respond better to both platinum- and non-platinum-containing regimens (Alsop et al, 2012). 
Knowing the $B R C A$ mutation status of a patient with ovarian cancer is important in terms of managing individual risk and identifying other family members at risk. In addition, a patient's BRCA1 and 2 mutation status can now inform the physician and patient regarding treatment outcomes, and, with the development of PARP inhibitors, offers patients the potential for personalised anticancer treatment.

\section{POLY (ADP-RIBOSE) POLYMERASE AND THE} DEVELOPMENT OF PARP INHIBITORS

The discovery of the first PARP was made over 50 years ago when researchers in Paul Mandel's laboratory observed the synthesis of a new polyadenylic acid after adding nicotinamide mononucleotide to rat liver extracts (Chambon et al, 1963). By 1980 it was known that this nuclear enzyme, PARP-1, was activated by DNA damage and played a pivotal role in the repair of DNA SSBs via the base-excision repair/single-strand break repair (BER/SSBR) pathway (Figure 2) (Benjamin and Gill, 1980). Seminal work by Sydney Shall's group subsequently demonstrated that PARP-1 was not only involved in the repair of SSBs, but inhibiting it could enhance the cytotoxic effects of methylating agents in leukaemic mice cells (Durkacz et al, 1980), suggesting that PARP inhibitors could act as chemosensitisers. There are now 17 members of the PARP nuclear superfamily and it is PARP-1 and 2 that are involved in DNA repair (Rouleau et al, 2010).

The first inhibitor of PARP, 3-aminobenzamide (3-AB), was identified over 30 years ago following the observation that nicotinamide and 5-methylnicotinamide competed with NAD + as a PARP substrate (Purnell and Whish, 1980). Poly (ADP-ribose) polymerase inhibitor development pipelines initially investigated the potential for PARP inhibition to act as potentiators of chemotherapy and radiotherapy (Ferraris, 2010). More recently, they have pursued their therapeutic application as single agents, selectively killing cells with defects in DNA repair pathways, such as those with BRCA1/2 mutations. There are currently four PARP inhibitors in Phase III development for ovarian cancer (Table 1). The most developed in the class is olaparib, a potent, oral inhibitor of PARP-1 and 2 that induces lethality in tumours with HRD, such as BRCA1/2 mutations (Evers et al, 2008; Rottenberg et al, 2008). Olaparib is associated with significant clinical benefit in high-grade ovarian cancers with germline and/or somatic mutations within the $B R C A 1 / 2$ genes (Fong et al, 2009; Audeh et al, 2010; Tutt et al, 2010; Gelmon et al, 2011; Ledermann et al, 2014; Kaufman et al, 2015; Oza et al, 2015). This topic is reviewed within this Supplement (Ledermann, 2015). Why single-agent PARP inhibitors are active in BRCAm cancers is explained below through the concept of 'synthetic lethality'.

A

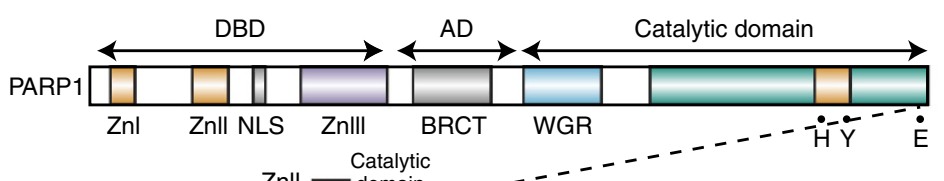

B

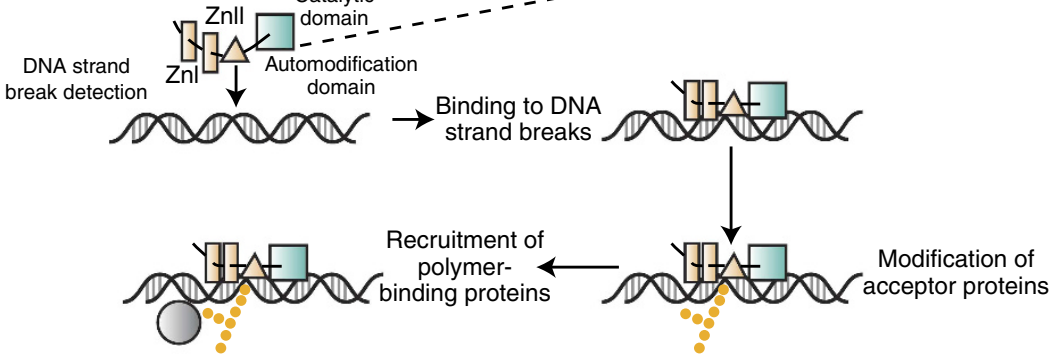

C

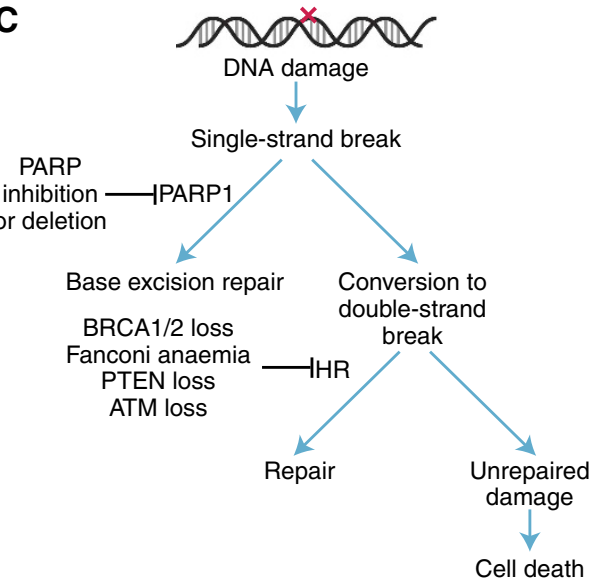

D
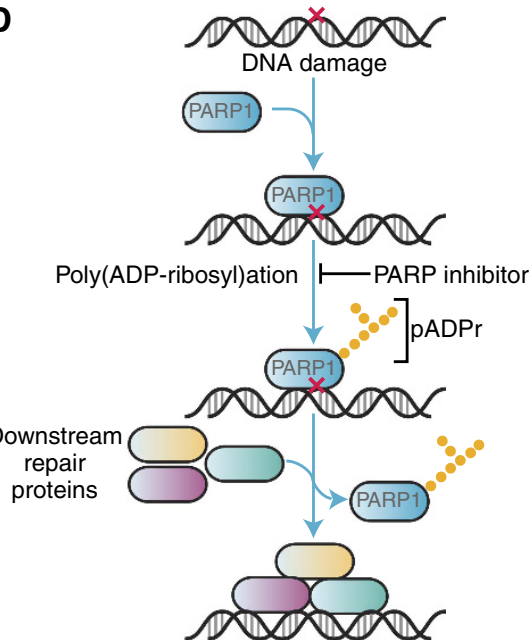

Figure 2. Base-excision repair/single-strand break pathway. (A) Structure of PARP1. (B) Activation of PARP1 in response to DNA damage. After binding to damaged DNA, the enzymatic activity of PARP1 increases following a conformational change to the active site. PARP1 synthesises poly(ADP) ribose chains that alter protein function and recruit additional proteins. (C) Role of PARP1 in base excision repair. (D) Model showing recruitment of DNA repair proteins following DNA damage. Abbreviations: AD, automodification domain; BRCT, BRCA1 C-terminal domain; DBD, DNA-binding domain; HR, homologous recombination; NLS, nuclear localisation signal; WGR, tyrptophan-glycine-arginine-rich domain; Zn, zinc finger. Note: Reproduced with permission from the American Society of Clinical Oncology (C) Scott et al, 2015). 
Table 1. PARP inhibitors in Phase III clinical trial development for ovarian cancer, 2015

\begin{tabular}{|c|c|c|c|c|c|}
\hline Agent & Company & $\mathrm{IC}_{50}$ & Ongoing clinical trials & Patient population & Indication \\
\hline \multirow[t]{4}{*}{$\begin{array}{l}\text { Olaparib } \\
\text { (AZD2281) }\end{array}$} & \multirow[t]{4}{*}{ AstraZeneca } & \multirow[t]{4}{*}{$\begin{array}{l}5 \mathrm{~nm} \text { (PARP1) } \\
1 \mathrm{~nm} \text { (PARP2) } \\
\text { (Menear et al, 2008) }\end{array}$} & SOLO1 (NCT01844986) & $\begin{array}{l}\text { BRCA-mutated, advanced (FIGO Stage III-IV), high- } \\
\text { grade serous/endometrioid; response (CR or PR) to initial } \\
\text { platinum-based chemotherapy }\end{array}$ & First line \\
\hline & & & SOLO2 (NCT01874353) & $\begin{array}{l}\text { BRCA-mutated, high-grade serous/endometrioid; } \\
\text { response }(C R \text { or } P R) \text { following } \geqslant 2 \text { lines of platinum-based } \\
\text { chemotherapy }\end{array}$ & Relapsed \\
\hline & & & SOLO3 (NCT02282020) & $\begin{array}{l}\text { Germline BRCA-mutated, platinum-sensitive relapsed, } \\
\text { high-grade serous/endometrioid }\end{array}$ & Relapsed \\
\hline & & & SOLOIST (NCT02392676) & $\begin{array}{l}\text { Platinum-sensitive relapsed, high-grade epithelial; } \\
\text { deficient DNA damage repair (must not be caused by } \\
\text { a germline BRCA mutation) }\end{array}$ & Relapsed \\
\hline $\begin{array}{l}\text { Niraparib } \\
\text { (MK4827) }\end{array}$ & $\begin{array}{l}\text { Merck (licensed } \\
\text { to Tesaro) }\end{array}$ & $\begin{array}{l}3.8 \mathrm{~nm} \text { (PARP1) } \\
2.1 \mathrm{~nm} \text { (PARP2) } \\
\text { (Jones et al, 2009) }\end{array}$ & NOVA (NCT01847274) & $\begin{array}{l}\text { BRCA-mutated or high-grade serous; sensitive to } \\
\text { penultimate platinum-based regimen; response } \\
\text { (CR or PR) to current platinum-based chemotherapy }\end{array}$ & Relapsed \\
\hline $\begin{array}{l}\text { Rucaparib } \\
\text { (AG014699) }\end{array}$ & Clovis Oncology & $\begin{array}{l}1.4 \mathrm{~nm} \text { (Ki; PARP1) } \\
0.5 \mathrm{~nm} \text { (Ki; PARP2) } \\
\text { (Thomas et al, 2007) }\end{array}$ & ARIEL3 (NCT01968213) & $\begin{array}{l}\text { High-grade serous/endometrioid; sensitive to } \\
\text { penultimate platinum-based regimen; response } \\
\text { (CR or PR) to current platinum-based chemotherapy }\end{array}$ & Relapsed \\
\hline $\begin{array}{l}\text { Talazoparib } \\
\text { (BMN-673) }\end{array}$ & Medivation & $\begin{array}{l}0.58 \mathrm{~nm} \text { (PARP1) } \\
\text { (Shen et al, 2013) }\end{array}$ & None & - & - \\
\hline $\begin{array}{l}\text { Veliparib (ABT- } \\
\text { 888) }\end{array}$ & AbbVie and BMS & $\begin{array}{l}5.2 \mathrm{~nm} \text { (PARP1) } \\
2.9 \mathrm{~nm} \text { (PARP2) } \\
\text { (Donawho et al, 2007) }\end{array}$ & NCT02470585 & Advanced (FIGO Stage III or IV), high-grade serous & First line \\
\hline
\end{tabular}

POLY (ADP-RIBOSE) POLYMERASE INHIBITORS AS SINGLE AGENTS IN BRCAm CANCERS-THE CONCEPT OF SYNTHETIC LETHALITY

In 2005, two articles published in Nature reported that cells deficient in BRCA1 and 2 were 100 - to 1000 -fold more sensitive to PARP inhibitors than $B R C A 1 / 2$ heterozygote or wild-type cell lines (Bryant et al, 2005; Farmer et al, 2005). Bryant et al used the PARP inhibitors NU1025 and AG14361, both forerunners to rucaparib (Clovis Oncology, Boulder, CO, USA). In mice xenografts, three out of five V-C8 tumours responded to a 5-day dosing of AG14361, with one mouse showing complete remission and no sign of tumour at autopsy. In addition, the articles reported an induction in $\gamma \mathrm{H} 2 \mathrm{AX}$ foci formation (representing DNA DSBs) and Rad51 foci formation (indicating functional $\mathrm{HR}$ repair) in the XRCC1-deficient EM9 (Chinese hamster ovary) cell lines. In the V-C8 cells, an increase in $\gamma \mathrm{H} 2 \mathrm{AX}$ foci formation, but not Rad51, was observed following exposure to NU1025.

In the Nature sister article, Farmer et al (2005) demonstrated the sensitivity of both BRCA1- and BRCA2-deficient cell lines to the specific inhibition of PARP-1 by two small-molecule inhibitors KU0058684 and KU0058948, forerunners to olaparib. They demonstrated that 24-h exposure to the PARP inhibitor resulted in permanent $\mathrm{G} 2 / \mathrm{M}$ cell-cycle arrest or apoptosis. They also reported a three-fold increase in sensitivity over the DNA-damaging agent cisplatin for BRCA1/2-deficient cells. Both research groups independently concluded that $B R C A$-deficient cells were selectively sensitive to PARP inhibition by a mechanism of 'synthetic lethality'.

'Synthetic lethality' is the concept by which cancer cells are selectively sensitive to the inactivation of two genes or pathways when inactivation of either gene or pathway alone is non-lethal (Kaelin, 2005). This proposed mechanism of synthetic lethality of PARP inhibitors in BRCA-deficient cells is outlined in Figure 3. Poly (ADP-ribose) polymerase inhibition leads to the accumulation of DNA SSBs that result in unrepaired stalled replication forks and ultimately DSBs. These DNA DSBs are normally repaired by the HRR pathway (Hoeijmakers, 2001). In HRR-defective cells, that is, those with BRCA1/2 mutations,
Endogenous DNA damage $\rightarrow$ Formation of single-strand DNA breaks (SSBs) $\rightarrow$ Repair of SSB by base excision repair (BER)
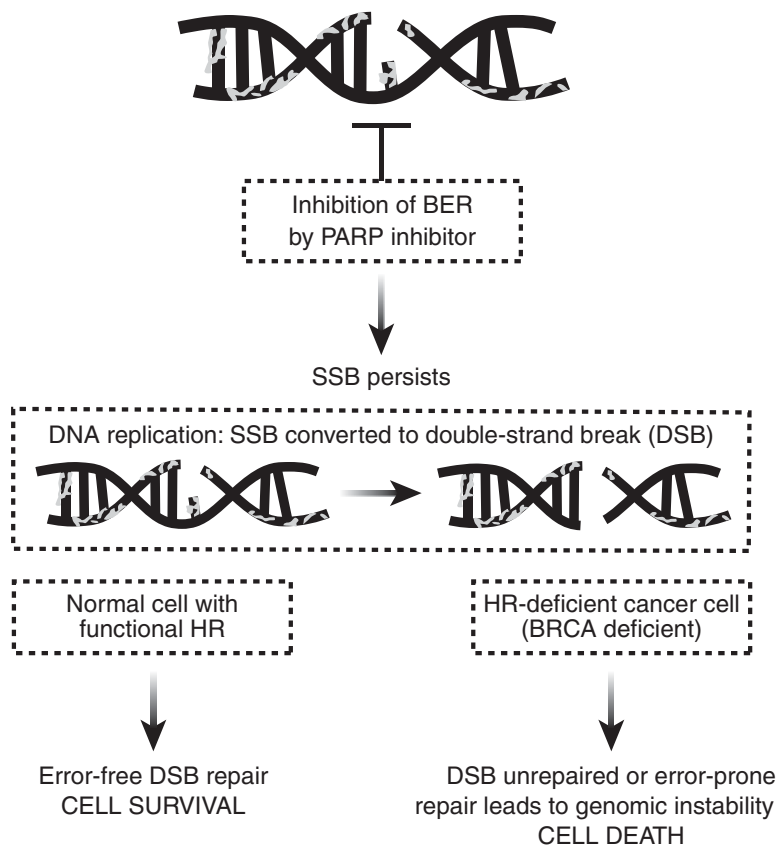

Figure 3. Synthetic lethality of PARP inhibitors in BRCA-deficient cells.

these DSBs are left unrepaired or are repaired in an error-prone way by alternative non-homologous end-joining DNA repair; both outcomes can result in genomic instability and ultimately cell death. Whereas, in cells with functional HRR, that is, those with heterozygous mutations or wild-type BRCA, DSBs will be accurately and efficiently repaired, and inhibiting PARP will not result in cell death. Clinical trials are now confirming these preclinical data demonstrating that, as a class, PARP inhibitors are active in BRCAm cancers. 


\section{FUTURE DIRECTIONS FOR PARP INHIBITORS}

The majority of ovarian cancers are not attributed to hereditary germline mutations in the BRCA1 and 2 genes (Venkitaraman, 2002), so a key question is whether single-agent PARP inhibitors can be used to treat patients within the larger ovarian cancer population. It is known that HRD is not exclusive to germline BRCAm cancers, for example; molecular analysis of HGSOC as part of The Cancer Genome Atlas revealed that approximately 50\% were shown to harbour HRD (Cancer Genome Atlas Research Network, 2011). This HRD included somatic BRCA mutations (6-8\%) and epigenetic silencing in non-BRCA genes, such as $A T M$ and $R A D 51$. In addition, by using a functional assay of HRR, Mukhopadhyay et al (2010) demonstrated that $50 \%$ of primary cultures generated from ascites in unselected HGSOC patients had HRD and were sensitive to PARP inhibitors. Developing a diagnostic signature of HRD in cancers is the focus of the ongoing rucaparib studies (www.clinicaltrials.org). Preliminary results from the rucaparib ARIEL 2 study (NCT 01891344) indicate efficacy in patients who have BRCAm ovarian cancer, but also in those who are $B R C A$ wild-type with high tumour genomic loss of heterozygosity (McNeish et al, 2014). The study hopes to develop a companion diagnostic to use within the ongoing Phase III trial (ARIEL 3; NCT01968213) of rucaparib in platinum-sensitive ovarian, fallopian tube or primary peritoneal high-grade cancer patients.

Another therapeutic approach is to induce HRD in otherwise HRR-competent cancers by altering the tumour microenvironment through hypoxia, or to combine PARP inhibitors with agents that can downregulate HRR, such as vascular endothelial growth factor (VEGF) inhibitors. This concept, known as 'contextual' synthetic lethality, could further broaden the application of this class of drugs and is the rationale behind many ongoing clinical trials. Preliminary data from a Phase II trial combining olaparib with the potent, oral VEGF tyrosine kinase inhibitor, cediranib, was shown to significantly improve progression-free survival over olaparib alone (9.0 months vs 17.7 months) (Liu et al, 2014); a confirmatory study is awaited.

Based on a wealth of preclinical data showing that PARP inhibitors potentiate the effects of DNA-damaging chemotherapy agents, such as the platinums, temozolomide and topoisomerase inhibitors (Delaney et al, 2000; Calabrese et al, 2004; Donawho et al, 2007), the original therapeutic intention of these agents was as chemopotentiators. Furthermore, inhibition of PARP has been shown to augment the antitumour activity of other agents that impair HRR, such as the DNA-synthesis inhibitor, gemcitabine (Virag and Szabo, 2002; Jacob et al, 2007). However, early clinical trials investigating multiple chemotherapy and PARP inhibitor combinations have reported enhanced myelosuppression as the main dose-limiting toxicity, and this may limit the future use of PARP inhibitors with chemotherapy (Chen, 2011).

Radiotherapy induces DNA damage by multiple mechanisms including base damage and single- and double-strand DNA breaks; damage that is dependent on PARP activity for its repair. Numerous in vitro and in vivo studies (Powell et al, 2010) using different classes of PARP inhibitors have reported enhancement of the cytotoxicity of radiation in a number of tumour types, including colorectal cancers (Calabrese et al, 2004) and gliomas (Dungey et al, 2009; Russo et al, 2009). More recently, work by Anthony Chalmers' group has shown that this radio-potentiation is enhanced in rapidly proliferating cells and cells defective in DNA DSB repair compared with normal tissue (Loser et al, 2010). These data support a role for combining radiotherapy and PARP inhibitors in patients with cancer, and clinical trials are finally underway (www.clinicaltrials.gov) with results eagerly awaited.

\section{SUMMARY}

Poly (ADP-ribose) polymerase inhibitors are an exciting new development in the treatment of cancer, with clinical trials of single agents showing significant benefits in patients with BRCAm ovarian cancer. The mechanism underlying this benefit is the HRD of BRCAm cancers. Historically, germline BRCA1/2 mutations were thought to be associated with approximately $10 \%$ of all ovarian cancers, but this is now known to be an underestimate. In addition, HRD is reported to be present in approximately $50 \%$ of all HGSOC cases. This suggests that the use of PARP inhibitors may have a much broader role in the treatment of ovarian cancer and the development of a validated HRD signature would facilitate this.

Finally, the recent licensing of olaparib in BRCAm ovarian cancer brings together over 50 years of research and is the first targeted treatment option for this patient population, taking another step further towards personalised medicine in ovarian cancer.

\section{ACKNOWLEDGEMENTS}

This supplement is sponsored by AstraZeneca. We thank Claire Routley, PhD, from Mudskipper Business Ltd, for editorial assistance funded by AstraZeneca.

\section{CONFLICT OF INTEREST}

Dr Yvette Drew has previously received honoraria as a clinical advisory board member for AstraZeneca and for Clovis Oncology.

\section{REFERENCES}

Alsop K, Fereday S, Meldrum C, deFazio A, Emmanuel C, George J, Dobrovic A, Birrer MJ, Webb PM, Stewart C, Friedlander M, Fox S, Bowtell D, Mitchell G (2012) BRCA mutation frequency and patterns of treatment response in BRCA mutation-positive women with ovarian cancer: a report from the Australian Ovarian Cancer Study Group. J Clin Oncol 30: 2654-2663.

Audeh MW (2014) Novel treatment strategies in triple-negative breast cancer: specific role of poly(adenosine diphosphate-ribose) polymerase inhibition. Pharmgenomics Pers Med 7: 307-316.

Audeh MW, Carmichael J, Penson RT, Friedlander M, Powell B, Bell-McGuinn KM, Scott C, Weitzel JN, Oaknin A, Loman N, Lu K, Schmutzler RK, Matulonis U, Wickens M, Tutt A (2010) Oral poly(ADP-ribose) polymerase inhibitor olaparib in patients with $B R C A 1$ or BRCA2 mutations and recurrent ovarian cancer: a proof-of-concept trial. Lancet 376: 245-251.

Benjamin RC, Gill DM (1980) ADP-ribosylation in mammalian cell ghosts. Dependence of poly(ADP-ribose) synthesis on strand breakage in DNA. J Biol Chem 255: 10493-10501.

Bhattacharyya A, Ear US, Koller BH, Weichselbaum RR, Bishop DK (2000) The breast cancer susceptibility gene BRCA1 is required for subnuclear assembly of Rad51 and survival following treatment with the DNA cross-linking agent cisplatin. J Biol Chem 275: 23899-23903.

Bolton KL, Chenevix-Trench G, Goh C, Sadetzki S, Ramus SJ, Karlan BY, Lambrechts D, Despierre E, Barrowdale D, McGuffog L, Healey S, Easton DF, Sinilnikova O, Benítez J, García MJ, Neuhausen S, Gail MH, Hartge P, Peock S, Frost D, Evans DG, Eeles R, Godwin AK, Daly MB, Kwong A, Ma ES, Lázaro C, Blanco I, Montagna M, D’Andrea E, Nicoletto MO, Johnatty SE, Kjær SK, Jensen A, Høgdall E, Goode EL, Fridley BL, Loud JT, Greene MH, Mai PL, Chetrit A, Lubin F, Hirsh-Yechezkel G, Glendon G, Andrulis IL, Toland AE, Senter L, Gore ME, Gourley C, Michie CO, Song H, Tyrer J, Whittemore AS, McGuire V, Sieh W, Kristoffersson U, Olsson H, Borg A, Levine DA, Steele L, Beattie MS, Chan S, Nussbaum RL, Moysich KB, Gross J, Cass I, 
Walsh C, Li AJ, Leuchter R, Gordon O, Garcia-Closas M, Gayther SA, Chanock SJ, Antoniou AC, Pharoah PD; EMBRACE; kConFab Investigators; Cancer Genome Atlas Research Network (2012) Association between BRCA1 and BRCA2 mutations and survival in women with invasive epithelial ovarian cancer. JAMA 307: 382-390.

Bryant HE, Petermann E, Schultz N, Jemth AS, Loseva O, Issaeva N, Johansson F, Fernandez S, McGlynn P, Helleday T (2009) PARP is activated at stalled forks to mediate Mre11-dependent replication restart and recombination. EMBO J 28: 2601-2615.

Bryant HE, Schultz N, Thomas HD, Parker KM, Flower D, Lopez E, Kyle S, Meuth M, Curtin NJ, Helleday T (2005) Specific killing of BRCA2deficient tumours with inhibitors of poly(ADP-ribose) polymerase. Nature 434: 913-917.

Buisson R, Dion-Côté A-M, Coulombe Y, Launay H, Cai H, Stasiak AZ, Stasiak A, Xia B, Masson J-Y (2010) Cooperation of breast cancer proteins PALB2 and piccolo BRCA2 in stimulating homologous recombination. Nat Struct Mol Biol 17(10): 1247-1254.

Calabrese CR, Almassy R, Barton S, Batey MA, Calvert AH, Canan-Koch S, Durkacz BW, Hostomsky Z, Kumpf RA, Kyle S, Li J, Maegley K, Newell DR, Notarianni E, Stratford IJ, Skalitzky D, Thomas HD, Wang LZ, Webber SE, Williams KJ, Curtin NJ (2004) Anticancer chemosensitization and radiosensitization by the novel poly(ADP-ribose) polymerase-1 inhibitor AG14361. J Natl Cancer Inst 96: 56-67.

Cancer Genome Atlas Research Network (2011) Integrated genomic analyses of ovarian carcinoma. Nature 474: 609-615.

Chambon P, Weill JD, Mandel P (1963) Nicotinamide mononucleotide activation of new DNA-dependent polyadenylic acid synthesizing nuclear enzyme. Biochem Biophys Res Commun 11: 39-43.

Chen A (2011) PARP inhibitors: its role in treatment of cancer. Chin J Cancer 30: $463-471$.

Chen S, Parmigiani G (2007) Meta-analysis of BRCA1 and BRCA2 penetrance. J Clin Oncol 25: 1329-1333.

Delaney CA, Wang LZ, Kyle S, Kyle S, White AW, Calvert AH, Curtin NJ, Durkacz BW, Hostomsky Z, Newell DR (2000) Potentiation of temozolomide and topotecan growth inhibition and cytotoxicity by novel poly(adenosine diphosphoribose) polymerase inhibitors in a panel of human tumor cell lines. Clin Cancer Res 6: 2860-2867.

Domchek SM, Friebel TM, Neuhausen SL, Wagner T, Evans G, Isaacs C, Garber JE, Daly MB, Eeles R, Matloff E, Tomlinson GE, Van't Veer L, Lynch HT, Olopade OI, Weber BL, Rebbeck TR (2006) Mortality after bilateral salpingo-oophorectomy in BRCA1 and BRCA2 mutation carriers: a prospective cohort study. Lancet Oncol 7: 223-229.

Donawho CK, Luo Y, Penning TD, Bauch JL, Bouska JJ, Bontcheva-Diaz VD, Cox BF, DeWeese TL, Dillehay LE, Ferguson DC, Ghoreishi-Haack NS, Grimm DR, Guan R, Han EK, Holley-Shanks RR, Hristov B, Idler KB, Jarvis K, Johnson EF, Kleinberg LR, Klinghofer V, Lasko LM, Liu X, Marsh KC, McGonigal TP, Meulbroek JA, Olson AM, Palma JP, Rodriguez LE, Shi Y, Stavropoulos JA, Tsurutani AC, Zhu GD, Rosenberg SH, Giranda VL, Frost DJ (2007) ABT-888, an orally active poly(ADP-ribose) polymerase inhibitor that potentiates DNA-damaging agents in preclinical tumor models. Clin Cancer Res 13: $2728-2737$.

Dungey FA, Caldecott KW, Chalmers AJ (2009) Enhanced radiosensitization of human glioma cells by combining inhibition of poly(ADP-ribose) polymerase with inhibition of heat shock protein 90 . Mol Cancer Ther 8: 2243-2254.

Durkacz BW, Omidiji O, Gray DA, Shall S (1980) (ADP-ribose)n participates in DNA excision repair. Nature 283: 593-596.

Evers B, Drost R, Schut E, de Bruin M, van der Burg E, Derksen PW, Holstege H, Liu X, van Drunen E, Beverloo HB, Smith GC, Martin NM, Lau A, O'Connor MJ, Jonkers J (2008) Selective inhibition of BRCA2deficient mammary tumor cell growth by AZD2281 and cisplatin. Clin Cancer Res 14: 3916-3925.

Farmer H, McCabe N, Lord CJ, Tutt AN, Johnson DA, Richardson TB, Santarosa M, Dillon KJ, Hickson I, Knights C, Martin NM, Jackson SP, Smith GC, Ashworth A (2005) Targeting the DNA repair defect in BRCA mutant cells as a therapeutic strategy. Nature 434: 917-921.

Ferraris DV (2010) Evolution of poly(ADP-ribose) polymerase-1 (PARP-1) inhibitors. From concept to clinic. J Med Chem 53: 4561-4584.

Fong PC, Boss DS, Yap TA, Tutt A, Wu P, Mergui-Roelvink M, Mortimer P, Swaisland H, Lau A, O'Connor MJ, Ashworth A, Carmichael J, Kaye SB, Schellens JH, de Bono JS (2009) Inhibition of poly(ADP-ribose) polymerase in tumors from BRCA mutation carriers. N Engl J Med 361: 123-134.
Gelmon KA, Tischkowitz M, Mackay H, Swenerton K, Robidoux A, Tonkin K, Hirte H, Huntsman D, Clemons M, Gilks B, Yerushalmi R, Macpherson E, Carmichael J, Oza A (2011) Olaparib in patients with recurrent high-grade serous or poorly differentiated ovarian carcinoma or triple-negative breast cancer: a phase 2, multicentre, open-label, non-randomised study. Lancet Oncol 12: 852-861.

Gudmundsdottir K, Ashworth A (2006) The roles of BRCA1 and BRCA2 and associated proteins in the maintenance of genomic stability. Oncogene 25: 5864-5874.

Hall JM, Lee MK, Newman B, Morrow JE, Anderson LA, Huey B, King MC (1990) Linkage of early-onset familial breast cancer to chromosome 17q21. Science 250: 1684-1689.

Hanker LC, Loibl S, Burchardi N, Pfisterer J, Meier W, Pujade-Lauraine E, Ray-Coquard I, Sehouli J, Harter P, du Bois A. AGO and GINECO study group (2012) The impact of second to sixth line therapy on survival of relapsed ovarian cancer after primary taxane/platinum-based therapy. Ann Oncol 23: 2605-2612.

Helleday T, Lo J, van Gent DC, Engelward BP (2007) DNA double-strand break repair: from mechanistic understanding to cancer treatment. DNA Repair (Amst) 6: 923-935.

Helleday T, Petermann E, Lundin C, Hodgson B, Sharma RA (2008) DNA repair pathways as targets for cancer therapy. Nat Rev Cancer 8: 193-204.

Hoeijmakers JH (2001) Genome maintenance mechanisms for preventing cancer. Nature 411: 366-374.

Hoeijmakers JH (2009) DNA damage, aging, and cancer. N Engl J Med 361: $1475-1485$.

Jacob DA, Bahra M, Langrehr JM, Boas-Knoop S, Stefaniak R, Davis J, Schumacher G, Lippert S, Neumann UP (2007) Combination therapy of poly (ADP-ribose) polymerase inhibitor 3-aminobenzamide and gemcitabine shows strong antitumor activity in pancreatic cancer cells. $J$ Gastroenterol Hepatol 22: 738-748.

Jones P, Altamura S, Boueres J, Ferrigno F, Fonsi M, Giomini C, Lamartina S, Monteagudo E, Ontoria JM, Orsale MV, Palumbi MC, Pesci S, Roscilli G, Scarpelli R, Schultz-Fademrecht C, Toniatti C, Rowley M (2009) Discovery of 2-\{4-[(3S)-piperidin-3-yl]phenyl\}-2H-indazole-7-carboxamide (MK-4827): a novel oral poly(ADP-ribose)polymerase (PARP) inhibitor efficacious in BRCA-1 and -2 mutant tumors. J Med Chem 52: 7170-7185.

Kaelin Jr WG (2005) The concept of synthetic lethality in the context of anticancer therapy. Nat Rev Cancer 5: 689-698.

Kaufman B, Shapira-Frommer R, Schmutzler RK, Audeh MW, Friedlander M, Balmaña J, Mitchell G, Fried G, Stemmer SM, Hubert A, Rosengarten O, Steiner M, Loman N, Bowen K, Fielding A, Domchek SM (2015) Olaparib monotherapy in patients with advanced cancer and a germ-line BRCA1/2 mutation. J Clin Oncol 33: 244-250.

Leavy O (2010) V(D)J recombination: RAG recombination centres. Nat Rev Immunol 10: 383.

Ledermann JA, El-Khouly F (2015) PARP inhibitors in ovarian cancer: clinical evidence for informed treatment decisions. Br J Cancer S1-S7; doi:10.1038/bjc.2015.395.

Ledermann JA, Harter P, Gourley C, Friedlander M, Vergote I, Rustin G, Scott CL, Meier W, Shapira-Frommer R, Safra T, Matei D, Fielding A, Spencer S, Dougherty B, Orr M, Hodgson D, Barrett JC, Matulonis U (2014) Olaparib maintenance therapy in patients with platinum-sensitive relapsed serous ovarian cancer: a preplanned retrospective analysis of outcomes by BRCA status in a randomised phase 2 trial. Lancet Oncol 15: $852-861$.

Liu JF, Barry WT, Birrer M, Lee JM, Buckanovich RJ, Fleming GF, Rimel B, Buss MK, Nattam S, Hurteau J, Luo W, Quy P, Whalen C, Obermayer L, Lee H, Winer EP, Kohn EC, Ivy SP, Matulonis UA (2014) Combination cediranib and olaparib versus olaparib alone for women with recurrent platinum-sensitive ovarian cancer: a randomised phase 2 study. Lancet Oncol 15: 1207-1214.

Loser DA, Shibata A, Shibata AK, Woodbine LJ, Jeggo PA, Chalmers AJ (2010) Sensitization to radiation and alkylating agents by inhibitors of poly(ADP-ribose) polymerase is enhanced in cells deficient in DNA double-strand break repair. Mol Cancer Ther 9: 1775-1787.

McNeish I, Coleman RL, Oza A, Konecny GE, O’Malley D, Kichendasse G, Scott C, Oaknin A, Floquet A, Park D, Brenton J, Lin K, Shetty S, Raponi M, Isaacson J, Rolfe L, Giordano H, Allen A, Swisher E (2014) Preliminary results of ARIEL2, a phase 2 open-label study to identify ovarian cancer patients likely to respond to rucaparib. European Society for Medical Oncology (ESMO) Annual Meeting, Madrid, Spain; 26-30 September; abstract 883PD. 
Menear KA, Adcock C, Boulter R, Cockcroft XL, Copsey L, Cranston A, Dillon KJ, Drzewiecki J, Garman S, Gomez S, Javaid H, Kerrigan F, Knights C, Lau A, Loh Jr VM, Matthews IT, Moore S, O'Connor MJ, Smith GC, Martin NM (2008) 4-[3-(4-Cyclopropanecarbonylpiperazine1-carbonyl)-4-fluorobenzyl]-2H-phth alazin-1-one: a novel bioavailable inhibitor of poly(ADP-ribose) polymerase-1. J Med Chem 51: 6581-6591.

Miki Y, Swensen J, Shattuck-Eidens D, Futreal PA, Harshman K, Tavtigian S, Liu Q, Cochran C, Bennett M, Ding W, Bell R, Rosenthal J, Hussey C, Tran T, McClure M, Frye C, Hattier T, Phelps R, Haugen-Strano A, Katcher H, Yakumo K, Gholami Z, Schaffer D, Stone S, Bayer S, Wray C, Bogden R, Dayananth P, Ward J, Tonin P, Narod S, Bristow PK, Norris FH, Helvering L, Morrison P, Rosteck P, Lai M, Barrett JC, Lewis C, Neuhausen S, Cannon-Albright L, Goldgar D, Wiseman R, Kamb A, Skolnick MH (1994) A strong candidate for the breast and ovarian cancer susceptibility gene BRCA1. Science 266: 66-71.

Mukhopadhyay A, Elattar A, Cerbinskaite A, Wilkinson SJ, Drew Y, Kyle S, Los G, Hostomsky Z, Edmondson RJ, Curtin NJ (2010) Development of a functional assay for homologous recombination status in primary cultures of epithelial ovarian tumor and correlation with sensitivity to poly (ADP-ribose) polymerase inhibitors. Clin Cancer Res 16: 2344-2351.

Neale MJ, Keeney S (2006) Clarifying the mechanics of DNA strand exchange in meiotic recombination. Nature 442: 153-158.

O'Driscoll M, Jeggo PA (2006) The role of double-strand break repairinsights from human genetics. Nat Rev Genet 7: 45-54.

Oza AM, Cibula D, Benzaquen AO, Poole C, Mathijssen RH, Sonke GS, Colombo N, Špaček J, Vuylsteke P, Hirte H, Mahner S, Plante M, Schmalfeldt B, Mackay H, Rowbottom J, Lowe ES, Dougherty B, Barrett JC, Friedlander M (2015) Olaparib combined with chemotherapy for recurrent platinum-sensitive ovarian cancer: a randomised phase 2 trial. Lancet Oncol 16: 87-97.

Powell C, Mikropoulos C, Kaye SB, Nutting CM, Bhide SA, Newbold K, Harrington KJ (2010) Pre-clinical and clinical evaluation of PARP inhibitors as tumour-specific radiosensitisers. Cancer Treat Rev 36: 566-575.

Purnell MR, Whish WJ (1980) Novel inhibitors of poly(ADP-ribose) synthetase. Biochem J 185: 775-777.

Risch HA, McLaughlin JR, Cole DE, Rosen B, Bradley L, Fan I, Tang J, Li S, Zhang S, Shaw PA, Narod SA (2006) Population BRCA1 and BRCA2 mutation frequencies and cancer penetrances: a kin-cohort study in Ontario, Canada. J Natl Cancer Inst 98: 1694-1706.

Risch HA, McLaughlin JR, Cole DE, Rosen B, Bradley L, Kwan E, Jack E, Vesprini DJ, Kuperstein G, Abrahamson JL, Fan I, Wong B, Narod SA (2001) Prevalence and penetrance of germline BRCA1 and BRCA2 mutations in a population series of 649 women with ovarian cancer. Am J Hum Genet 68: 700-710.

Rottenberg S, Jaspers JE, Kersbergen A, van der Burg E, Nygren AO, Zander SA, Derksen PW, de Bruin M, Zevenhoven J, Lau A, Boulter R, Cranston A, O'Connor MJ, Martin NM, Borst P, Jonkers J (2008) High sensitivity of BRCA1-deficient mammary tumors to the PARP inhibitor AZD2281 alone and in combination with platinum drugs. Proc Natl Acad Sci USA 105: 17079-17084.

Rouleau M, Patel A, Hendzel MJ, Kaufmann SH, Poirier GG (2010) PARP inhibition: PARP1 and beyond. Nat Rev Cancer 10: 293-301.

Russo AL, Kwon HC, Burgan WE, Carter D, Beam K, Weizheng X, Zhang J, Slusher BS, Chakravarti A, Tofilon PJ, Camphausen K (2009) In vitro and in vivo radiosensitization of glioblastoma cells by the poly (ADP-ribose) polymerase inhibitor E7016. Clin Cancer Res 15: 607-612.

Saito Y, Fujimoto H, Kobayashi J (2013) Role of NBS1 in DNA damage response and its relationship with cancer development. Transl Cancer Res 2013 2(3): 178-189.

Scott CL, Swisher EM, Kaufmann SH (2015) Poly (ADP-ribose) polymerase inhibitors: recent advances and future development. J Clin Oncol 33: 1397-1406.

Shen Y, Rehman FL, Feng Y, Boshuizen J, Bajrami I, Elliott R, Wang B, Lord CJ, Post LE, Ashworth A (2013) BMN 673, a novel and highly potent PARP1/2 inhibitor for the treatment of human cancers with DNA repair deficiency. Clin Cancer Res 19: 5003-5015.

Siegel R, Naishadham D, Jemal A (2012) Cancer statistics, 2012. CA Cancer J Clin 62: 10-29.

Takata M, Sasaki MS, Sonoda E, Morrison C, Hashimoto M, Utsumi H, Yamaguchi-Iwai Y, Shinohara A, Takeda S (1998) Homologous recombination and non-homologous end-joining pathways of DNA double-strand break repair have overlapping roles in the maintenance of chromosomal integrity in vertebrate cells. EMBO J 17: 5497-5508.

Tan DS, Rothermundt C, Thomas K, Bancroft E, Eeles R, Shanley S, ArdernJones A, Norman A, Kaye SB, Gore ME (2008) 'BRCAness' syndrome in ovarian cancer: a case-control study describing the clinical features and outcome of patients with epithelial ovarian cancer associated with BRCA1 and BRCA2 mutations. J Clin Oncol 26: 5530-5536.

Tassone P, Tagliaferri P, Perricelli A, Blotta S, Quaresima B, Martelli ML, Goel A, Barbieri V, Costanzo F, Boland CR, Venuta S (2003) BRCA1 expression modulates chemosensitivity of BRCA1-defective HCC1937 human breast cancer cells. Br J Cancer 88: 1285-1291.

Thomas HD, Calabrese CR, Batey MA, Canan S, Hostomsky Z, Kyle S, Maegley KA, Newell DR, Skalitzky D, Wang LZ, Webber SE, Curtin NJ (2007) Preclinical selection of a novel poly(ADP-ribose) polymerase inhibitor for clinical trial. Mol Cancer Ther 6: 945-956.

Tutt A, Robson M, Garber JE, Domchek SM, Audeh MW, Weitzel JN, Friedlander M, Arun B, Loman N, Schmutzler RK, Wardley A, Mitchell G, Earl H, Wickens M, Carmichael J (2010) Oral poly(ADP-ribose) polymerase inhibitor olaparib in patients with $B R C A 1$ or $B R C A 2$ mutations and advanced breast cancer: a proof-of-concept trial. Lancet 376: $235-244$.

Venkitaraman AR (2002) Cancer susceptibility and the functions of BRCA1 and BRCA2. Cell 108: 171-182.

Virag L, Szabo C (2002) The therapeutic potential of poly(ADP-ribose) polymerase inhibitors. Pharmacol Rev 54: 375-429.

Wooster R, Neuhausen SL, Mangion J, Quirk Y, Ford D, Collins N, Nguyen K, Seal S, Tran T, Averill D et al. (1994) Localization of a breast cancer susceptibility gene, BRCA2, to chromosome 13q12-13. Science 265: 2088-2090.

World Health Organization (2008) GLOBOCAN statistics. Available at http:// globocan.iarc.fr/.

Yang H, Jeffrey PD, Miller J, Kinnucan E, Sun Y, Thoma NH, Zheng N, Chen PL, Lee WH, Pavletich NP (2002) BRCA2 function in DNA binding and recombination from a BRCA2-DSS1-ssDNA structure. Science 297: 1837-1848.

Zhong Q, Peng HL, Zhao X, Zhang L, Hwang WT (2015) Effects of BRCA1- and BRCA2-related mutations on ovarian and breast cancer survival: a meta-analysis. Clin Cancer Res 21: 211-220. 